Gut, 1979, 20, 493-498

\title{
High flow oxygen therapy for pneumatosis coli
}

\author{
S. HOLT ${ }^{1}$, H. M. GILMOUR, T. A. S. BUIST, K. MARWICK, AND \\ R. C. HEADING
}

From the Departments of Therapeutics and Clinical Pharmacology, Pathology, and Diagnostic Radiology, The Royal Infirmary, Edinburgh

SUMMARY Symptomatic and radiological resolution of pneumatosis coli was achieved by intermittent high flow oxygen therapy in five patients. In each case the extent of the disease was defined by colonoscopy and contrast radiography before treatment. Despite the confirmation of pneumocyst resolution, recurrence of colonic gas cysts was noted in two patients at six months and one year after treatment. Bacteriological studies indicated that resolution of the disease, induced by oxygen therapy, was not associated with eradication of anerobic bacteria from stool and colonic mucosa. The clinical features and response to treatment of this group of patients are discussed, with particular reference to previously reported methods of oxygen administration.

Primary pneumatosis coli is a disease of unknown aetiology, in which multiple gas-filled cysts of varying size and distribution are found in the large intestine. Its prevalence in the general population is difficult to assess as the disease may be asymptomatic, but it seems to be rare. We have previously noted an incidence of two cases in 6553 consecutive post mortem examinations (Holt et al., 1978). Two varieties of pneumatosis coli are recognised. It may be secondary to intestinal obstruction, infarction, inflammatory bowel disease or trauma but more frequently is of the primary idiopathic variety (Marshak et al., 1977). The pattern of the disease may have changed, as a review of the literature by Koss in 1952 identified only 13 of 213 cases of pneumatosis cystoides intestinalis with lesions restricted to the large bowel, whereas more recent reports imply a predilection for the gas cysts to occur in the left hemicolon without small intestinal involvement (Smith et al., 1958; Varano and Bonanno, 1973; Shallal et al., 1974; Wyatt, 1975; Marshak et al., 1977). Clinically, pneumatosis coli may be asymptomatic or manifest by persistent troublesome or intermittent symptoms, and in certain cases may undergo spontaneous resolution. Despite the lack of knowledge of its aetiology, successful treatment with prolonged remission has been achieved by high flow oxygen therapy (Forgacs et al., 1973; Wyatt, 1975).

\footnotetext{
${ }^{1}$ Address for correspondence: Dr Stephen Holt, University Department of Therapeutics and Clinical Pharmacology, The Royal Infirmary, Edinburgh EH3 9YW.
}

Received for publication 23 January 1979
Although a number of authors have reported resolution of pneumatosis cystoides intestinalis with oxygen therapy, there is no published series in which a consistent investigative and therapeutic approach has been adopted. We describe five patients with primary pneumatosis coli, in whom symptomatic and radiological resolution of disease has resulted from a standardised regime of intermittent high flow oxygen therapy.

\section{Methods}

PATIENT STUDY AND TREATMENT

Five patients with primary pneumatosis coli (Table 1) underwent high flow oxygen therapy (Table 2) by a modification of the method of Down and Castleden (1975). Barium meal and follow-through, double contrast barium enema, colonoscopy, sigmoidoscopy, and biopsy before and after treatment were performed to define the extent of pneumatosis and to identify any associated gastrointestinal disease. Studies of pulmonary function with twice daily measurement of forced expiratory volume, vital capacity and blood gases throughout the assessment permitted identification of patients with respiratory disease, monitoring of treatment, and the early recognition of oxygen toxicity in the lungs. The inspired oxygen concentration was estimated by catheter sampling in the nasopharynx during inspiration and was found to be between 60 and $70 \%$.

BACTERIOLOGICAL STUDY

Specimens of faeces were obtained at sigmoidoscopy 
Table 1 Details of five patients with pneumatosis coli

\begin{tabular}{|c|c|c|c|c|c|}
\hline Patient & Age/sex & $\begin{array}{l}\text { Radiological extent of } \\
\text { disease }\end{array}$ & Associated disease & Clinical features & $\begin{array}{l}\text { Follow-up } \\
\text { period }\end{array}$ \\
\hline 1 & $59 \mathrm{~F}$ & $\begin{array}{l}\text { Descending and sigmoid } \\
\text { colon }\end{array}$ & $\begin{array}{l}\text { Diverticular disease of } \\
\text { sigmoid colon, } \\
\text { osteomalacia }\end{array}$ & $\begin{array}{l}\text { Five-year history of intermittent slimy diarrhoea, mid- } \\
\text { abdominal colic, excessive flatus, and slight rectal } \\
\text { bleeding }\end{array}$ & $1 \frac{1}{2} \mathrm{yr}$ \\
\hline 2 & $69 \mathrm{~F}$ & Total colon & $\begin{array}{l}\text { Anaplastic carcinioma of } \\
\text { tonsil (age } 42 \mathrm{yr} \text { ) }\end{array}$ & $\begin{array}{l}\text { Four month history of intermittent diarrhoea, copious } \\
\text { flatus, and slight rectal bleeding }\end{array}$ & $1 \frac{1}{2} \mathrm{yr}$ \\
\hline $\begin{array}{l}3 \\
4\end{array}$ & $\begin{array}{l}68 \mathrm{M} \\
63 \mathrm{M}\end{array}$ & $\begin{array}{l}\text { Sigmoid colon } \\
\text { Splenic flexure to } \\
\text { sigmoid colon }\end{array}$ & $\begin{array}{l}\text { Diabetes mellitus } \\
\text { Cerebrovascular disease, } \\
\text { epilepsy, chronic } \\
\text { bronchitis }\end{array}$ & $\begin{array}{l}\text { Continuous rectal mucus discharge for } 8 \mathrm{w} \\
\text { Profuse, bubbly, watery diarrhoea with excessive flatus } \\
\text { for } 6 \mathrm{~m} \text {. Crepitant mass in left hypochondrium }\end{array}$ & $\begin{array}{l}3 \mathrm{yr} \\
9 \mathrm{~m}\end{array}$ \\
\hline 5 & $55 \mathrm{~F}$ & $\begin{array}{l}\text { Distal } \frac{1}{8} \text { transverse colon } \\
\text { and proximal } \frac{1}{8} \text { of } \\
\text { descending colon with } \\
\text { small sigmoid segment }\end{array}$ & $\begin{array}{l}\text { Osteoarthrosis of } \\
\text { lumbar spine }\end{array}$ & $\begin{array}{l}\text { Four-week history of lower abdominal pain with episodes } \\
\text { of abdominal distension }\end{array}$ & $9 \mathrm{~m}$ \\
\hline
\end{tabular}

Table 2 Method and monitoring of high flow oxygen therapy

Patient at rest in bed, in protected environmen

Twice daily clinical assessment

Humidified oxygen delivered by MC mask (6 $1 / \mathrm{min})$ and nasal cannulae (4 1/min)

Frequent check of oxygen flow rates

Measurement of inspiratory oxygen concentration at start of therapy

Intermittent therapy with three one-hour break periods, at 10.00,

16.00 , and 20.00 hours

Estimation of daily arterial blood gases (one hour after morning break)

Measurement of FEV and VC twice daily

Daily plain abdominal radiograph

Chest radiograph on alternate days

and immediately cultured. An initial dilution of 1 in 100 was prepared by emulsifying $0 \cdot 1 \mathrm{~g}$ faeces in $10 \mathrm{ml}$ $1 \%$ glucose broth which had been rendered anaerobic by pre-steaming and storage in an oxygen-free atmosphere for 24 hours. Serial 10 -fold dilutions were then prepared from this primary dilution. Plates of culture media (Table 3 ) for the isolation of anaerobic organisms were stored in an oxygen-free atmosphere for at least 24 hours before use. Media 1 and 2 were seeded by spreading the surface of the plates with $0 \cdot 1$ $\mathrm{ml}$ of varying dilutions. Plates of media 3 to 13 each received five single drops $(0.02 \mathrm{ml})$ from a '50 dropper' pipette at varying dilutions, using the method of Miles et al. (1938).

All plates were seeded in duplicate and the anaerobic plates were immediately sealed in Baird and Tatlock jars. A suitable dilution-that is, one yielding between 10 and 50 colonies per drop-was chosen and the colonies on each plate were counted, the mean value being used to calculate the number of organisms present in $1 \mathrm{~g}$ of stool. Gram-stained films were prepared from the counted colonies to provide a presumptive check on the types of organisms present.

Samples of gas cyst walls and colonic mucosa obtained at sigmoidoscopy were placed directly into Robertson's cooked meat broth medium and incubated anaerobically at $37^{\circ} \mathrm{C}$ overnight. Sub- cultures from the meat medium were transferred to aerobic and anaerobic blood agar plates, Mannitol salt agar, MacConkey's agar, and Willis and Hobb's medium. Quantitative bacteriological study was not undertaken. The isolated organisms were classified according to their morphology, gram-staining properties, and cultural characteristics and were identified by reference to the tables of Cowan and Steel (1974) and API tables (Analytab Products Inc., 1976).

\section{Results}

The extent of involvement of the large bowel by pneumocysts could not be predicted from the patients' symptoms or signs, which were variable, and no associated gastrointestinal disease was detected. Plain abdominal radiography during treatment demonstrated gradual disappearance of the cysts, which occurred in all cases within five days. The patients remained comfortable during the treatment and oxygen toxicity was not observed. Symptomatic relief was promptly achieved and lasting, except in case 5 where abdominal pain, unrelated to the presence of pneumatosis, persisted. In case 4 , the crepitant abdominal mass was impalpable by the third day of treatment. Chest radiography and continuous monitoring of the pulmonary vital capacity were normal, except in patient 4 who had evidence of chronic obstructive airways disease. All the patients have been reviewed with follow-up periods from nine months to three years and radiological resolution is maintained in three out of the five patients. In case 2 and case 5 (Table 1) pneumocysts have reappeared one year and six months respectively, after treatment. In patient 5 , recurrent disease of a similar extent to that noted before oxygen therapy is now apparent and bowel symptoms with excessive flatus and slight rectal bleeding have appeared for the first time. In patient 2 , who had total colon disease, gas cysts have recurred 
Table 3 Details of bacteriological analyses

\begin{tabular}{|c|c|c|c|c|}
\hline Medium no. & Description of medium & $\begin{array}{l}\text { Atmospheric } \\
\text { condition }\end{array}$ & $\begin{array}{l}\text { Duration of } \\
\text { incubation }(h r)\end{array}$ & $\begin{array}{l}\text { Organisms } \\
\text { counted }\end{array}$ \\
\hline $\begin{array}{l}1 \\
2\end{array}$ & $\begin{array}{l}\text { Columbia agar* and } 10 \% \text { horse blood } \\
\text { Reinforced clostridial agar (Oxoid) enriched with } 1 \% \text { glucose, } 10 \% \text { horse blood, } \\
\text { and } 1.0 \mathrm{ml} 3 \% \text { aqueous China Blue } / 100 \mathrm{ml} \text { media }\end{array}$ & $\begin{array}{l}\text { Aerobic } \\
5 \% \mathrm{CO}_{2}: \mathrm{H}_{2}\end{array}$ & $\begin{array}{l}24 \\
96\end{array}$ & $\begin{array}{l}\text { Total aerobes } \\
\text { Total anaerobes }\end{array}$ \\
\hline 3 & MacConkey agar* & Aerobic & 24 & $\begin{array}{l}\text { Coliform, } \\
\text { enterococci }\end{array}$ \\
\hline 4 & Mannitol salt agar* & Aerobic & 24 & Staphylococci \\
\hline 5 & Thallous acetate tetrayolium glucose agar (TITG) & Aerobic & 24 & Streptococci \\
\hline 6 & Sabouraud's agar*-incubated at $25^{\circ} \mathrm{C}$ & Aerobic & 48 & Yeasts \\
\hline 7 & Rogosa agar & $10 \% \mathrm{CO}_{2}$ : air & 48 & Aerobic \\
\hline 8 & $1 \%$ glucose agar & $10 \% \mathrm{CO}_{2}:$ air & 48 & $\begin{array}{l}\text { lactobacilli } \\
\text { and } \\
\text { bifidobacteria }\end{array}$ \\
\hline 9 & Rogosa agar & $5 \% \mathrm{CO}_{2}: \mathrm{H}_{2}$ & 48 & Anaerobic \\
\hline 10 & $1 \%$ glucose agar & $5 \% \mathrm{CO}_{2}: \mathrm{H}_{2}$ & 48 & $\begin{array}{l}\text { lactobacilli } \\
\text { and } \\
\text { bifidobacteria }\end{array}$ \\
\hline 13 & $\begin{array}{l}\text { Reinforced clostridial agar* with } 10 \% \text { horse blood and } 100 \mu \mathrm{g} / \mathrm{ml} \text { neomycin and } \\
7.5 \mu \mathrm{g} / \mathrm{ml} \text { vancomycin }\end{array}$ & $5 \% \mathrm{CO}_{2}: \mathrm{H}_{2}$ & 48 & Bacteroides \\
\hline
\end{tabular}

*Supplied by Oxoid Limited, Wade Road, Basingstoke, Hampshire RG24 OPW.

only in the left hemicolon is association with complete symptomatic relapse.

Colonoscopy before treatment revealed the pleomorphic nature of the gas cysts, which were shown by radiology to be predominantly submucosal in position. In case 2 , multiple small submucosal blebs were noted at colonoscopy before therapy and were due to submucosal pneumocysts, up to $0.5 \mathrm{~cm}$ in maximum diameter. This colonoscopic finding contrasts with case 4 where larger tense cysts up to 3 $\mathrm{cm}$ in diameter were observed to be partially occluding the large bowel lumen. In the first two patients, who had suffered rectal bleeding, petechial haemorrhages were noted both on the 'domes' of some of the cysts and also in a halo distribution around their bases.

Biopsy of the cyst walls resulted in a 'popping noise' indicating the presence of gas under some degree of tension. Light microscpy of the cyst walls demonstrated a patchy lining of histiocytic-type cells with occasional multinucleate giant cells. After treatment, the mucosa of the large bowel appeared normal at colonoscopy, except for some redundancy of mucosal folds, especially marked in case 2 . Posttreatment biopsy of the colon, taken from areas known to be affected before treatment, demonstrated a slight chronic inflammatory infiltrate in the lamina propria of the mucosa. No significant changes were apparent in the submucosa at the sites where cysts were previously known to be present. In particular, submucosal multinucleate giant cells were not identified in any of the colonic biopsies taken after oxygen treatment.

Qualitative and quantitative faecal bacterial studies of four patients (cases 1, 2, 4, and 5) demon- strated a range of organisms that are encountered in the faeces of normal Scottish subjects (Hill et al., 1971). It is apparent that the type and quantity of bacteria in the faeces were not altered to any great extent by oxygen therapy (Figure). In particular, there was no evidence of eradication of anaerobic organisms. Considering the cyst wall before treatment and colonic mucosa after treatment, no unusual organisms were isolated (Table 4). Although species of enterobacteria were consistently grown from the cyst wall, they persisted after treatment as did species of clostridia. No single species or group of organisms could be implicated in the pathogenesis of the pneumocysts and there did not appear to be a displacement of anaerobic organisms from the bowel wall with oxygen therapy.

\section{Discussion}

Although the aetiology of primary pneumatosis coli remains uncertain, the possibility that gas-forming bacteria create and maintain the pneumocysts has recently been advocated (Down and Castleden, 1975). The experimental induction of pneumatosis by clostridia in rats (Yale, 1975) and the suggestion that high tissue concentrations of oxygen achieved during oxygen breathing may kill anerobic gas-producing bacteria (Down and Castleden, 1975) seem to favour a bacterial hypothesis. Resolution of the disease in humans by high flow oxygen therapy (Forgacs et al., 1973), and perhaps by broad spectrum antibiotics (Wandtke et al., 1977; Holt et al., 1978), provides further circumstantial evidence for a bacterial causation of pneumatosis cystoides intestinalis.

In our patients, several gas-forming organisms 


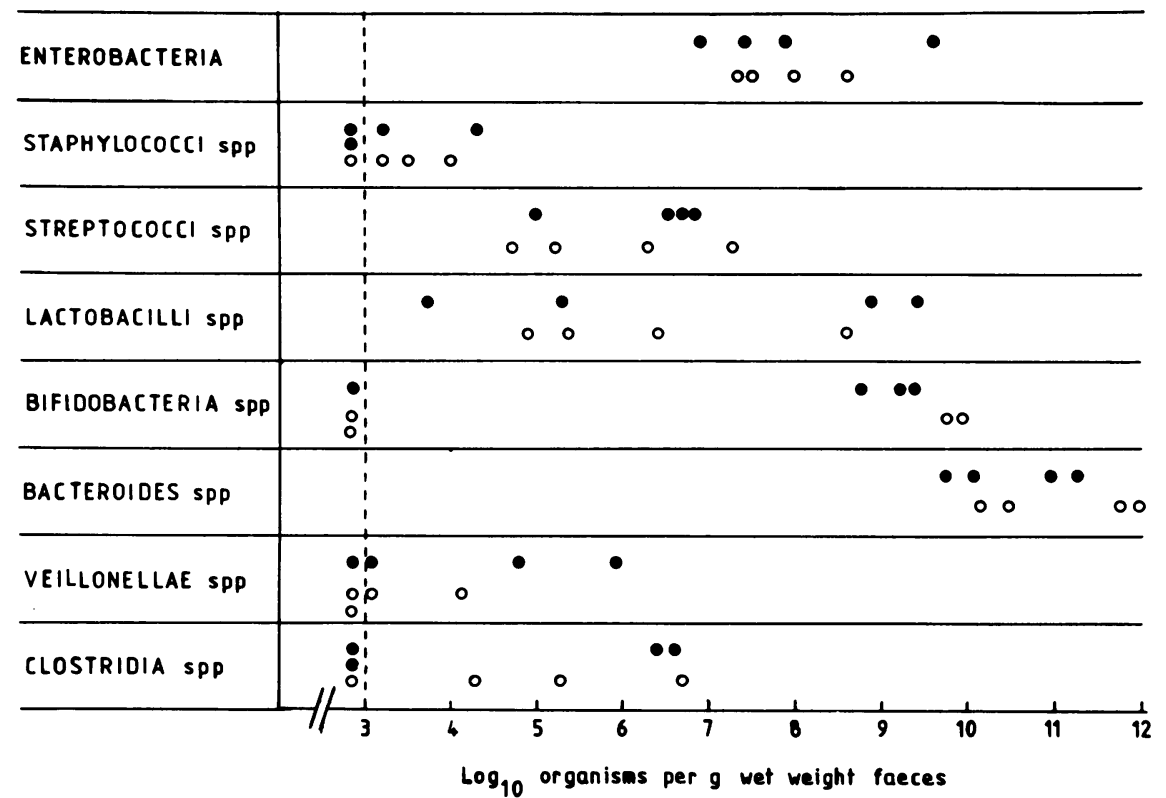

Figure Bacteria isolated from four patients' faeces before (closed circles) and after (open circles) treatment. The vertical dotted line represents the lower limit of sensitivity of the counting method employed.

Table 4 Bacteria cultured from gas cysts and colonic mucosa before and after oxygen therapy

\begin{tabular}{|c|c|c|c|c|c|c|c|c|}
\hline & \multicolumn{8}{|c|}{ Patient no. } \\
\hline & \multicolumn{2}{|l|}{1} & \multicolumn{2}{|l|}{2} & \multicolumn{2}{|l|}{3} & \multicolumn{2}{|l|}{4} \\
\hline & Before & After & Before & After & Before & After & Before & After \\
\hline $\begin{array}{l}\text { Enterobacteria } \\
\text { Staphylococci spp }\end{array}$ & + & + & + & + & $\begin{array}{l}+ \\
+\end{array}$ & + & + & + \\
\hline $\begin{array}{l}\text { Streptococcispp } \\
\text { Clostridia spp }\end{array}$ & $\begin{array}{l}+ \\
+\end{array}$ & $\begin{array}{l}+ \\
+\end{array}$ & & + & + & + & + & $\stackrel{t}{+}$ \\
\hline
\end{tabular}

were cultured from stool and cyst wall before treatment but we were unable to identify any unusual types or abnormal numbers of bacteria. A reasonably consistent growth of enterobacteria was obtained from the cyst wall before oxygen therapy but the organisms persisted after treatment, as did species of clostridia. Both these types of organisms have been implicated as a cause of the disease in animals (Naeslund, 1924; Yale, 1975), but their role in the pathogenesis of the disease in man remains uncertain. Although Down and Castleden (1975) presented the hypothesis that high tissue concentrations of oxygen occurring during therapy kill any anaerobic gas-producing bacteria, our results indicate that the anaerobic faecal flora in subjects with pneumatosis coli are not substantially altered by oxygen treatment. If there is significant microbial action at the colonic mucosa in this condition, it is not demonstrable by marked changes in the faecal bacterial populations that we have studied, and it is not revealed by our qualitative studies of the bacteria associated with the colonic mucosa in affected sites. Based on our findings, we cannot implicate bacteria as the prime pathogenesis of gas cyst formation and maintenance in humans with primary pneumatosis coli.

The composition of gas within the cysts has been estimated as nitrogen $80-90 \%$, oxygen $5-16 \%$, and carbon dioxide $0 \cdot 3-4 \cdot 0 \%$ (Lee et al., 1977), and free diffusion of gas between the bowel lumen and capillaries is known to occur (Forgacs et al., 1973). In normal circumstances, gas loculi do not persist in the body because the total partial pressure of gases in the venous blood is less than atmospheric pressure (Nunn, 1977), and thus the mechanism of gas cyst maintenance is difficult to explain. The gases within the cyst are under some degree of tension as indicated 
by the 'popping' noise that is obtained when the pneumocyst is punctured at biopsy. This finding has led to the suggestion that gas is produced within the pneumocyst at a rate that exceeds absorption (Forgacs et al., 1973). It is the overall denitrogenation of the blood that occurs during the breathing of high concentrations of oxygen that leads to obliteration of the gas cysts. The net effect in pneumatosis coli is an alteration of the cyst capillary diffusion gradient in favour of absorption and resolution occurs (Forgacs et al., 1973; Gruenberg et al., 1977).

Various methods of oxygen therapy have been described (Table 5) but an optimum procedure has not been agreed. It was initially suggested that arterial oxygen concentrations in excess of $40 \mathrm{kPa}$ (300 mm mercury) were necessary for resolution (Forgacs et al., 1973) but more recent experience, including that of the present series, suggests that lower concentrations are also effective (Gruenberg et al., 1977; Lee et al., 1977). Masks and nasal cannulae are more acceptable to patients, for oxygen tents are restricting and may result in a feeling of isolation for the patient (Lee et al., 1977). It would appear unnecessary to supplement inspired oxygen concentration during rest periods as suggested by Gruenberg et al., (1977), for we were able to discontinue therapy for short periods without any apparent prejudice to resolution of the disease.

Anxiety has been expressed about the possibility of oxygen toxicity (Gruenberg et al., 1977) and perhaps even carbon dioxide narcosis (Lee et al., 1977) with this form of treatment and, consequently, pulmonary function should be monitored by clinical examination, measurement of the vital capacity, daily blood gas estimations and chest radiography during the period of oxygen administration. A decrease in the pulmonary vital capacity may be the most useful early indicator of oxygen toxicity in man (Clark, 1971). None of our patients showed evidence of oxygen toxicity during or after treatment but it is notable that only one of our patients (case 4) had evidence of chronic obstructive airways disease, an allegedly common association with pneumatosis coli (Doub and Shea, 1960).

To date, it has been uncertain whether or not oxygen therapy affords a permanent cure of pneumatosis coli (Wyatt, 1975). A number of authors have noted recurrence of the condition after treatment (Table 5), but resolution has followed further oxygen therapy(Höflin and Van der Linden, 1974). Incomplete initial resolution may account for some of the apparent recurrences and aggressive oxygen therapy is recommended for at least 48 hours (Wyatt, 1975). Despite the confirmation of pneumocyst eradication by contrast radiography and colonoscopy, recurrent disease has occurred in two out of five patients in our series. Bacterial gas production seems to be the most likely cause of the disease (Gillon et al., 1978) and it is possible that failure to eradicate anaerobic gasproducing bacteria renders recurrent disease inevitable in some patients.

Although pneumatosis coli is an uncommon disorder, the nature of associated symptoms and lack of clinical awareness of the condition may result in misdiagnosis, sometimes with unnecessary surgical intervention (Thomson et al., 1977). It is important to note that gas cysts may vary in size and extent without specific treatment and that spontaneous resolu-

Table 5 Various methods of oxygen therapy for pneumatosis coli

\begin{tabular}{|c|c|c|c|c|c|c|c|}
\hline Author & $\begin{array}{l}\text { No. of } \\
\text { treated } \\
\text { patients }\end{array}$ & $\begin{array}{l}\text { Oxygen } \\
\text { concentra- } \\
\text { tion } \\
(\%)\end{array}$ & $\begin{array}{l}\text { Flow rate } \\
\text { (1/min) }\end{array}$ & Mode of delivery & $\begin{array}{l}\text { Arterial } \\
\mathrm{PO}_{2}(k P a)\end{array}$ & $\begin{array}{l}\text { Length of } \\
\text { treatment } \\
\text { (days) }\end{array}$ & Follow-up \\
\hline $\begin{array}{l}\text { Forgacs } \\
\quad \text { et al. (1973) }\end{array}$ & 1 & $70-75$ & 一 & Modified head tent & $28-50 \cdot 7$ & 6 & No recurrence at $6 \mathrm{~m}$ \\
\hline $\begin{array}{l}\text { Höflin and } \\
\text { Van der Linde } \\
\text { (1974) }\end{array}$ & $\begin{array}{c}2 \\
\text { en }\end{array}$ & $68-72$ & - & Oxygen tent & 一 & 5 & $\begin{array}{l}\text { Widespread recurrence at } 5 \text { and } \\
13 \mathrm{~m}\end{array}$ \\
\hline $\begin{array}{l}\text { Down and } \\
\text { Castleden } \\
(1975)\end{array}$ & 1 & 一 & $\begin{array}{l}8 \\
4\end{array}$ & $\begin{array}{l}\text { MC mask, } \\
\text { nasal catheters }\end{array}$ & $51 \cdot 7$ & 6 & $-\pi$ \\
\hline $\begin{array}{l}\text { Simon et al. } \\
\text { (1975) }\end{array}$ & 4 & 70 & - & Hudson mask & $22-45 \cdot 5$ & $5-8$ & Recurrence in one patient at $6 \mathrm{~m}$ \\
\hline Wyatt (1975) & 6 & $70-75$ & 8 & Pneumask (Vickers Ltd.) & 40 & 4-7 & $\begin{array}{l}\text { Two patients relapsed at } 1 \mathrm{yr} \text { and } \\
18 \mathrm{~m}\end{array}$ \\
\hline $\begin{array}{l}\text { Britten-Jones } \\
\quad(1975)\end{array}$ & 2 & 一 & $8-12$ & Intranasal catheter & $17 \cdot 3-33 \cdot 3$ & $4-7$ & No recurrence at 15 and $4 \mathrm{~m}$ \\
\hline $\begin{array}{l}\text { Watson } \\
\text { (1976) }\end{array}$ & 1 & - & $\begin{array}{l}4 \\
4\end{array}$ & $\begin{array}{l}60 \% \text { face mask } \\
\text { nasal catheter }\end{array}$ & $40 \cdot 5$ & 5 & $-\pi$ \\
\hline $\begin{array}{l}\text { Gruenberg et al. } \\
\text { (1977) }\end{array}$ & 2 & 70 & 5 & $\begin{array}{l}\text { Non-rebreathing mask, nasal } \\
\text { cannulae }\end{array}$ & $31 \cdot 7-34$ & 4-10 & $\begin{array}{l}\text { No recurrence at } 10 \mathrm{~m} \text { and } 3 \mathrm{~m} \\
\text { respectively }\end{array}$ \\
\hline $\begin{array}{l}\text { Lee } e t \text { al. } \\
\quad(1977)\end{array}$ & 2 & $55-70$ & 16 & Hudson mask & $13 \cdot 7-38 \cdot 7$ & 5 & No recurrence at $18 \mathrm{~m}$ \\
\hline Present series & 5 & $60-70$ & $\begin{array}{l}6 \\
4\end{array}$ & $\begin{array}{l}\text { MC mask, } \\
\text { nasal cannulae }\end{array}$ & $18 \cdot 7-38 \cdot 7$ & $4-5$ & $\begin{array}{l}\text { Two patients relapsed at } 1 \mathrm{yr} \text { and } \\
6 \mathrm{~m}\end{array}$ \\
\hline
\end{tabular}


tion may occur (Bloch, 1977; Marshak et al., 1977). Our experience indicates that intermittent high flow oxygen therapy provides a safe, comfortable, and simple form of treatment for patients with symptomatic pneumatosis coli.

We thank Mr A. J. Duff and Mr T. J. McNair who kindly referred patients 3 and 5 to our care and Professor J. G. Collee for his guidance with the interpretation of the bacteriological study.

\section{References}

Analytab Products Inc. (1975). Analytical Profile IndexEnterobacteriaceae and Other Gram Negative Bacteria. Analytab Products: Plainview, NY.

Bloch, C. (1977). The natural history of pneumatosis coli. Radiology, 123, 311-314.

Britten-Jones, R. (1975). A major advance in the management of pneumatosis coli. Australian and New Zealand Journal of Surgery, 45, 367-371.

Clark, J. M., and Lambertsen, C. J. (1971). Rate of development of pulmonary $\mathrm{O}_{2}$ toxicity in man during $\mathrm{O}_{2}$ breathing at 2.0 ata. Journal of Applied Physiology, 30, 739-752.

Cowan, S. T., and Steel, K. J. (1974). Manual for the Identification of Medical Bacteria. Cambridge University Press: Cambridge.

Doub, H. P., and Shea, J. J. (1960). Pneumatosis cystoides intestinalis. Journal of the American Medical Association, 172, 1238-1242.

Down, R. H. L., and Castleden, W. M. (1975). Oxygen therapy for pneumatosis coli. British Medical Journal, 1, 493-494.

Forgacs, P., Wright, P. H., and Wyatt, A. P. (1973). Treatment of intestinal gas cysts by oxygen breathing. Lancet, $1,579-582$.

Gillon, J., Tadesse, K., Logan, R. F. A., Holt, S., and Sircus, W. (1978). Breath hydrogen in pneumatosis cystoides intestinalis (Abstract). Gut, 19, A973.

Gruenberg, J. C., Batra, S. K., and Priest, R. J. (1977). Treatment of pneumatosis cystoides intestinalis with oxygen. Archives of Surgery, 112, 62-64.

Hill, M. J., Drasar, B. S., Aries, V., Crowther, J. S., Hawksworth, G., and Williams, R. E. O. (1971). Bacteria and aetiology of cancer of large bowel. Lancet, 1, 95-100.

Höflin, F., and Van der Linden, W. (1974). Pneumatosis cystoides intestinalis treated by oxygen breathing. Scandinavian Journal of Gastroenterology, 9, 427-428.

Holt, S., Stewart, I. C., Heading, R. C., and Macpherson,
A. I. S. (1978). Resolution of primary pneumatosis coli. Journal of the Royal College of Surgeons of Edinburgh, 23, 297-299.

Koss, L. G. (1952). Abdominal gas cysts (pneumatosis cystoides intestinorum hominis): an analysis with a report of a case and a critical review of the literature. Archives of Pathology, 53, 523-549.

Lee, S. P., Coverdale, H. A., and Nicholson, G. I. (1977). Oxygen therapy for pneumatosis coli: a report of two cases and a review. Australian and New Zealand Journal of Medicine, 7, 44-46.

van der Linde, W. (1974). Pneumatosis cystoides intestinalis: recidief na $\mathrm{O}_{2}$ behandeling. Tijdschrift voor Gastroenterologie, 17, 281-286.

Marshak, R. H., Lindner, A. E., and Maklansky, D. (1977). Pneumatosis cystoides coli. Gastrointestinal Radiology, 2, 85-89.

Miles, A. A., Misra, S. S., and Irwin, J. O. (1938). Estimation of the bactericidal power of the blood. Journal of Hygiene (Cambridge), 38, 732-749.

Naeslund, J. (1924). Zur Kenntnis der Pneumatosis cystoides intestinorum: pathologisch-anatomische und experimentelle Studien. Thesis (Upsala), l. Marcus: Stockholm.

Nunn, J. F. (1977). Applied Respiratory Physiology, 2nd edn., p. 130. Butterworth: London.

Shallal, J. A., van Heerden, J. A., Bartholomew, L. G., and Cain, J. C. (1974). Pneumatosis cystoides intestinalis. Mayo Clinic Proceedings, 49, 180-184.

Smith, W. G., Anderson, M. J., Jr, and Pemberton, H. W. (1958). Pneumatosis cystoides intestinalis involving left portion of colon: report of four cases diagnosed at sigmoidoscopy. Gastroenterology, 35, 528-533.

Thomson, W. O., Gillespie, G., and Blumgart, L. H. (1977). The clinical significance of pneumatosis cystoides intestinalis: a report of 5 cases. British Journal of Surgery, 64, 590-592.

Varano, V. J., and Bonanno, C. A. (1973). Colonoscopic findings in pneumatosis cystoides intestinalis. American Journal of Gastroenterology, 59, 353-360.

Wandtke, J., Skucas, J., Spataro, R., and Bruneau, R. J. (1977). Pneumatosis intestinalis as a complication of jejunoileal bypass. American Journal of Roentgenology, 129, 601-604.

Watson, R. D. S. (1976). Successful treatment of pneumatosis coli with oxygen. British Medical Journal 1, 199.

Wyatt, A. P. (1975). Prolonged symptomatic and radiological remission of colonic gas cysts after oxygen therapy. British Journal of Surgery, 62, 837-839.

Yale, C. E. (1975). Etiology of pneumatosis cystoides intestinalis. Surgical Clinics of North America, 55, 12971302. 